\title{
MUSIK TRADISI SEBAGAI SALAH SATU SUMBER PENGEMBANGAN KARYA CIPTA
}

\section{TRADITION MUSIC AS ONE OF THE SOURCES OF DEVELOPMENT OF COPYRIGHT WORKS}

\author{
Wimbrayardi ${ }^{1}$ \\ ${ }^{1}$ Jurusan Sendratasik, Fakultas Bahasa dan Seni, Universitas Negeri Padang \\ ${ }^{(*)} \bowtie$ (e-mail) wimbrayardi@gmail.com
}

\begin{abstract}
Abstrak
Kreativitas para seniman musik untuk meningkatkan apresiasi di dalam masyarakat, dengan menciptakan bentuk baru yang sumbernya dari idiom-idiom kesenian tradisional. Untuk mengembangkannya perlu menganalisis konsep-konsep yang ada dalam seni tradisi tersebut. Hal ini agar tidak meninggalkan nilai-nilai yang terkandung di dalam kesenian tradisi itu, selain itu dengan menciptakan musik baru diharapkan dapat menambah perbendaharaan suatu bentuk kesenian tradisi dalam bentuk baru yang menjadi kebanggaan masyarakat pendukung kesenian itu
\end{abstract}

Kata kunci: tradisional, kesenian, mencipta, karya, musik

\begin{abstract}
Creativity of music artists to increase appreciation in society, by creating new forms whose sources are from traditional art idioms. To develop it, it is necessary to analyze the concepts in the art of tradition. This is so as not to abandon the values contained in the traditional arts, besides that by creating new music it is hoped that it can add to the treasury of a form of traditional art in a new form that is the pride of the arts supporters
\end{abstract}

Keywords: traditional, arts, creating, works, music 


\section{Pendahuluan}

Kesenian tradisi adalah suatu bentuk kesenian yang telah membudaya dan berkembang dalam suatu masyarakat, dan berada sudah cukup lama dalam masyarakat pendukungnya. Disamping itu kesenian tradisi merupakan milik bersama, dan dipelihara bersama-sama pula oleh masyarakat, yang terikat akan adat istiadat, aturan-aturan, atau norma yang digunakan oleh mayarakat tersebut. Tak salah kiranya kesenian disebut sebagai salah satu identitas budaya suatu bangsa, atau masyarakat yang memeliharannya.

Kesenian tradisional merupakan kesenian yang berlaku secara mentradisi dalam kehidupan sosial budaya masyarakat di suatu tempat. Biasanya kesenian tradisional merupakan media bagi masyarakat untuk berbagai kepentingan yang bersifat tradisi pula. Sebab itu kesenian tradisional merupakan milik secara bersama oleh suatu masyarakat. Karena itu pula musi tersebut digunakan dan difungsikan untuk kepentingan bersama pula. Sehingga kesenian tradisional identik dengan kehidupan masyarakat yang komunal, hidup dalam pikiran kolektif dan solidaritas kedaerahan

Memandang kesenian tradisi merupakan warisan budaya bagi masyarakat, sebab itu seniman sebagai penggiat dan pelaku dari pada aktivitas kesenian tersebut sangat penting keberadaannya dalam masyarakat. Karena pertumbuhan kesenian tradisi terkait kepada usaha dan upaya yang mereka lakukan, baik pada tingkat kreativitas dan kerelaannya untuk mewariskan dan memelihara serta mngembangkannya kesenian tradisi tersebut di tengahtengah masyarakat. Karena tanpa kehadiran seniman tersebut, kesenian tradisi sulit untuk dilestarikan dan pengembangannya terhadap tantangan budaya global sekarang ini.

Namun selain keberadaan seniman, perkembangan kesenian salah satu seni tradisi, juga terkait kepada pengelolaan atau usaha yang dilakukan oleh kaum-kaum atau secara berkampung dan bernagari. Pada masa lalu kesenian merupakan kebanggaan bersama yang dipelihara dan digalakkan pertumbuhannya secara bersama-sama oleh masyarakat. Masalah pewarisan dan pengelolaan aktivitasnya dalam masyarakat dikelola secara bersama dan didukung bersama. Artinya, perkembangan kesenian masa itu tidak diserahkan saja kehidupannya kepada pewaris atau tuo-tuo kesenian saja. Namun masyarakat dimana kesenian itu tumbuh dan berkembang secara bersama ikut menjadi penggiat atau penggerak bagi keberlangsungan kehidupan aktivitas kesenian tersebut di dalam masyarakatnya.

Keberadaan kesenian tersebut merupakan simbol harga diri dan kebanggaan bersama bagi masyarakat. Masa lalu jarang dari masyarakat mengabaikan peranan kesenian tradisional dalam kehidupan sosialnya. Akan tetapi dia ikut mendukung kehadiran kesenian tradisional tersebut sebagai bahagian dari pada dirinya sendiri. Dampak dari dukungan moral dan rasa memiliki yang tinggi tersebut ke atas budaya kesenian dalam masyarakat, menyebabkan kesenian tersebut dapat hidup dan berkembang.

Masa kini setelah segalanya berubah, baik sistem pemerintahan, peradaban dan gaya hidup serta kebudayaan dan politik di berbagai daerah, berdampak pula ke persoalan budaya tradisi di berbagai daerah tersebut. Sering kesenian tradisi masa kini menjadi sesuatu yang diabaikan keberadaannya oleh masyarakat pendukungnya. Pada sebagian masyarakat di berbagai daerah, kesenian tradisi masa kini tidak lagi menjadi hal yang sakral dan yang perlu diagungkan atau dibanggakan, dan kurang dipandang lagi sebagai bagian dari identitas budaya mereka. Oleh karenanya, pada setiap berbagai perhelatan dalam kehidupan masyarakat, baik dalam konteks adat maupun dalam konteks hiburan rakyat, sepertinya 
keberadaan kesenian tradisi jarang digunakan dalam peristiwa tersebut. Memandang kepada perilaku masyarakat yang rata-rata tidak lagi membudayakan budaya seni kesenian dalam kehidupan sosialnya, berakibat kepada kurangnya perhatian masyarakat dan pemilik kesenian tradisi tersebut dalam hal untuk mengembangkan dan mempertahankannya, sehingga kesenianan tersebut tetap bertahan di dalam daerahnya sendiri.

Masa kini yang terlihat dalam menggerakan berbagai aktivitas pertunjukan kesenian tradisi hanya lebih banyak dari golongan seniman tua. Mereka memiliki tenaga dan waktu yang terbatas. Selain itu mereka juga memiliki akses yang terbatas pula. Hal ini berpengaruh kepada usaha mereka untuk berjuang guna melestarikan dan pengambangan kesenian tradisi. Seniman tua yang disebut dengan tuo kesenian ini, seperti dibiarkan sendirian membudayakan dan melestarkan kesenian tradisi di dalam masyarakat. Meskipun kehadirannya sebagai seniman bila mempertunjukan kesenian tradisi dapat diterima oleh masyarakat. Artinya profesi dan usaha mereka melestarkan kesenian tradisi tidak juga ditolak oleh masyarakat. Hanya saja masyarakat kurang mendukung usaha mereka untuk melestarikan kesenian tradisi tersebut.

Bila mana keadaan seperti ini terus berlangsung dalam masyarakat dimana kesenian tradisi itu hidup dan menjadi kebanggan maasyarakat selama ini, dapat diprediksi mungkingan dalam waktu tidak lama lagi kesenian tradisi akan punah dan berkubur bersama senimannya (Marzam \& Mansyur, 2018, p. 94). Gejala ini yang sehingga kini masih berlaku dalam kehidupan masyarakat sekarang ini. Bila saja perkembangannya dapat diurus dan dibantu pembudayaannya oleh berbagai pihak, mungkin seniman yang tua-tua tersebut tidak kesulitan untuk mengembangkan kesenian tradisi yang mereka geluti selama ini.

Kesenian tradisional sebagai warisan, yang masih dipelihara dan bisa sampai pada generasi sekarang masih dibutuhkan oleh pemiliknya (Maestro \& Sinaga, 2018). Dalam proses pewarisan ini dapat terjadi modifikasi, berkenan dengan modifikasi inilah biasanya ada perselisihan pendapat. Ada yang ingin mempertahankan keasliannya semurni-murninya, tetapi pada waktu yang sama ada yang merasa harus melakukan penyesuaian dengan perkembangan baru. Kalau yang terjadi bukan hanya modifikasi, melainkan perubahan yang besar dari pada itu yaitu transformasi, maka kita telah berhadapat dengan suku bangsa dengan jaringan yang lebih luas yaitu nasional. Tuntutan pembangunan nasional membuat orientasi yang mengarahkan pencipta musik berubah pula. Ada fungsi baru yang harus dipenuhi, ada forum-forum baru yang harus dimasuki. Misi kesenian dan berbagai macam festival adalah contoh dari forum-forum baru itu yang sifatnya nasional. Golongan musik sering sekali dipengaruhi oleh penata-penata musik baru di bidang musik, seperti organisasi/kursus musik dan sekolah seni diberbagai tingkatan.

\section{Metode}

Penelitian ini menggunakan pendekatan kualitatif, seperti yang dikemukakan oleh (Moleong, 2002, p. 12) menyatakan bahwa penelitian kualitatif adalah penelitian yang menghasilkan data deskriptif, yaitu berupa kata-kata dan tindakan dari orang-orang dan prilaku yang diamati sebagai data utama, data kedua berupa data tambahan yang berasal dari studi kepustakaan. Selanjutnya (Moleong, 2002, p. 12) mengatakan bahwa hasil fenomena yang diamati tidak berupa angka-angka tetapi koefisien hubungan antara variabel data yang berupa kata-kata atau gambaran.

Metode deskriptif analisis digunakan untuk meneliti status kelompok manusia atau suatu objek, suatu kondisi, suatu sistem pemikiran dan suatu peristiwa pada masa sekarang. 
Tujuan penelitian deskriptif adalah mendiskripsikan secara akurat mengenai faktor-faktor dan sifat-sifat serta hubungan antara fenomena yang diselidiki. Dengan demikian penelitian kualitatif perlu melihat, meninjau, dan mengumpulkan informasi dan kemudian mengungkapkan serta menjabarkan secara tepat yang diteliti.

\section{Hasil dan Pembahasan}

Orang percaya bahwa intuisi atau inspirasi memegang peranan yang penting di dalam aktivitas mencipta. Dari pengalaman estetik, manusia memperoleh kesan dalam kehidupannya, dan manusia cendrung ingin mengabadikan kesan yang dimilikinya. Kesankesan inilah yang kemudian dituangkan dan diabadikan dalam karya cipta.

Ada beberapa unsur yang berperan dalam proses karya cipta musik. Maka usaha memberikan tinjauan atau penilaian terhadap karya cipta perlu memperhatikan unsur-unsur tersebut, kedudukan seniman sebagai pencipta (creator), ide dan media yang berpangkal pada seniman dan mencoba menganalisis nilai-nilai teknis dan estetis serta nilai ekspresi dari musik tradisi yang akan dikembangkan dalam bentuk karya cipta baru. Untuk penghayatan tersebut dibutuhkan kepekaan rasa (sensitifitas) terhadap unsur-unsur seni dan nilai-nilai estetis serta kepekaan terhadap lingkungan dimana musik tradisi itu hidup dan dimiliki oleh masyarakatnya. Pada hal ini dinamai dengan nilai intrinsik seni adalah nilai non visual (tidak tampak) pada karya cipta, yang hanya dapat ditanggapi dengan rasa.

Tantangan seniman pada akhirnya adalah masalah kreativitas sejauh mana para seniman yang hidup dalam dunianya, dunia tradisi yang tidak sepenuhnya terbentuk dengan mengekspresikan idiom-idiom yang pas (Wuri, Wimbrayardi, \& Marzam, 2015). Musik warisan bisa menjadi kekayaan budaya, dalam arti menjadi sumber penciptaan namun musikmusik baru harus diciptakan. Musik warisan itu harus diidentifikasikan kembali mana yang menjadi unsur esensialnya, baik secara struktural maupun secara fungsional. Jika ingin "melestarikan" musik tersebut haruslah dengan memberinya fungsi baru dengan tetap mempertahankan unsur-unsur struktural yang esensial.

Menciptakan musik baru tanpa memperhitungkan musik yang telah menjadi warisan. Maka sang seniman harus akrab dengan nilai-nilai tradisinya dalam karyanya akan terasa "warna" tradisinya. Pada proses penciptaan yang pertama pemahaman terhadap tradisi dan karya yang telah menjadi warisan. Menciptakan sesuatu yang baru, tetapi masih memelihara unsur-unsur esensial serta idiom-idiom dan fungsinya. Untuk bisa menciptakan karya musik yang bersumberkan musik tradisi ada beberapa yang harus dipahami antara lain:

\section{Ide yang Bersumber Musik Tradisi}

Pada dasarnya karya cipta musik merupakan media komunikasi antara seniman sebagai kreator dengan masyarakat sebagai apresiator. Karya cipta bersifat komunikatif karena menjadi bentuk pernyataan yang dibutuhkan oleh hubungan masyarakat. Ide karya cipta yang bersumberkan pada kehidupan musik tradisi merupakan ide yang didukung oleh sifat kesucian dari nilai musik tradisi itu sendiri, yang melahirkan berbagai kaidah dan nilai. Ide yang bersumberkan musik tradisi, merupakan ide yang tidak terikat pada pikiran konvensional dan bertolak dari kebutuhan masyarakat sesuai dengan perkembangan kebudayaan yang meliputi setiap zaman.

Media seni mempunyai arti sarana yang menentukan batasan-batasan diri lingkup musik tradisi. Nedia sebagai sarana aktifitas dapat menghasilkan karya cipta setelah melalui proses berdasarkan pertimbangan artistik (nilai estetik). Media dalam musik tradisi dapat 
juga diartikan sebagai bahan (materi) yaitu elemen disik yang digunakan untuk membuat karya cipta.

\section{Nilai Teknis dan Estetis}

Setiap karya cipta apakah itu bunyi, gerak dan suara menghasilkan karya cipta apabila didukung oleh kemampuan teknis dan estetis dari seniman. Nilai Teknis; Media sebagai sarana juga diartikan sebagai bahan atau alat. Dalam garapan musik bahan atau alat menuntut kepandaian cara atau kemampuan menggunakan yang disebut teknik. Kemampuan teknik dalam karya cipta sudah ada pada zaman dahulu manusia mulai berkarya cipta, yang sampai sekarang para seniman cukup mampu mengotak-atik media atau alat secara teknik. Kemampuan teknik yang melahirkan nilai teknis dalam karya cipta tida hanya terbatas dalam penguasaan bahan dan peralatan berkarya, tetapi juga dalam menggarap unsur-unsur seni. Sekalipun menggarap unsur-unsur seni tersebut juga menuntut kepakaan rasa.

Nilai Estetis; Tuntutan teknik tidak satu-satunya pernyataan dalam karya cipta, sering dikatakan bahwa penguasaan teknik atau ketrampilan (skill) adalah tuntutan dasar proses penggarapan ide menjadi karya cipta, Ini berarti bahwa dalam menggarap unsur-unsur estetis sebagai langkah lanjut dalam mencipta atau dalam menentukan azaz-azaz estetik (Djelantik, Rahzen, \& Suryani, 1999). Seniman perlu ditunjang dengan kemampuan teknik atau ketrampilan, bahkan kemampuan teknis itu sendiri saling berpengaaruh dengan azaz etetis.

Karya yang diciptakan seniman merupakan hasil pergulatan dalam mencari dan mengekspresikan diri dengan idiom-idiom yang estetik dan komunikasi untuk sebuah "publik" yang sedang berubah. Untuk memahami seniman harus tahu tentang potensi dirinya sebagai yang bergerak pada penciptaan karya musik, maka dalam hal ini penulis memaparkan proses kreatif dari musik tradisi adalah sember pengembangan karya musik.

\section{Fenomena Musik Tradisi}

Dalam membaca fenomena musik tradisi seniman dapat melakukan pendekatan reinterpretasi sehingga menemukan apa yang diinginkan, karena sebagai seniman kepekaan menangkap fenomena itu sangatlah penting. Musik Tradisi bukan saja mampu menumbuhkan suasana kreatif, inovatif dan produktif bagi seniman, tapi juga akan menimbulkan bentuk karya baru yang bersumberkan musik tradisi.

\section{Menemukan Gagasan dari Musik Tradisi}

Setelah membaca fenomena musik tradisi, langkah berikutnya adalah menarik tema sesuai ide atau gagasan sehingga ditemukan sebuah statemen lengkap tentang musik tradisi untuk dikembangkan menjadi karya cipta baru. Seniman harus menemukan gagasan musikal musik tradisi dari fenomena kehidupan, untuk itu dalam menemukan gagasan dengan pendekatan tradisi agar rancangan ayang akan di buat tidak akan menghilangkan warna dan roh musik tradisi itu sendiri. Dengan demikian rancangan atau tema yang menjadi pemikiran seniman perlu memadukan pendekatan tradisi dan kontemporer, secara tematis maupun pengolahan komposisi serta instrumen yang digunakan, yang paling penting dalam menggarap karya cipta musik baru adalah semangat musik tradisi itu harus menjadi benang merah dalam karya musik.

\section{Berimajinasi Musikal Tradisi}

Musik adalah tiruan bunyi-bunyian yang adda disekeliling kita dan musik juga rekayasa bunyi, bunyi itu dibuat, direkayasa tidak saja menyerupai citra lingkungan atau alam tetapi 
lebih dari itu bunyi "dicipta" oleh seniman menurut citra, angan-angan, mimpi dan kodrtanya sebagai manusia (Suka Hardjana 2003). Seniman secara umum pastilah mempunyai kemampuan berimajinasi, kemampuan tersebut bisa diolah menjadi kemampuan imajinasi musikal yang bersumber musik tradisi. Dalam berimajinasi seniman pasti menembus ruang estetis musik tradisi yang dijabarkan menjadi rangkaian karya cipta dengan segala pertimbangan teknik maupun pengolahan komposisi, sehingga ruang imajinasi musikal yang bersumberkan musik tradisi bisa dipahami sebagai pemicu gagasan baru.

\section{Eksperimentasi}

Proses eksperimentasi dimulai dengan membuat rancangan karya cipta, jika konsep sudah ditentukan, maka seniman harus melakukan ekperimen sesuai dengan kebutuhan dalam konsep karya cipta. Selanjutnya mencipta rancangan karya cipta musik berdasarkan musik tradisi harus jelas, ini berdassarkan pengalaman ekspresi musikal terhadap estetik musik tradisi yang dimiliki oleh para seniman. Karena perkembangan musik tidak hanya seni auditif, tetapi sudah menjadi kosumsi seni pertunjukan yang perlu diterjemahkan secara luas. Bahasa ungkap musik tidak harus melalui instrumen musik yang lazim, tetapi pemanfaatan benda-benda atau media yang ada di sekeliling kita juga mampu menghasilkan sebuah karya cipta musik. Hal ini tergantung daya kreativitas serta kepekaan seniman itu sendiri. Pemanfaatan untuk melibatkan beberapa unsur seni yang lain, akan memikat dan menghasilkan warna baru bila perpaduan dari karya cipta itu menggunakan konsep kesetaraan.

\section{Kesimpulan}

Berdasarkan hasil pengukuran dari penelitian talempong dapat ditrik simpulan sebagai berikut; Talempong merukan kesenian tradisional Minangkabau dimana susunan secara tangga nada atau nada setiap ddaerah mempunyai frekwensi berbeda, sesuai dengan kebutuhan dimana talempong itu tumbuh dalam kehidupan masyarakatnya. Terkain dengam simpulan tersebut, disarankan agar dimasa mendatang perlu diadakan kajian lebih mendalam terhadap nada-nada taleompong yang ada di Minangkabau secara kelompok.

\section{References}

Djelantik, A. A. M., Rahzen, T., \& Suryani, N. N. M. (1999). Estetika: sebuah pengantar. Masyarakat Seni Pertunjukan Indonesia.

Maestro, E., \& Sinaga, F. S. S. (2018). Kearifan Lokal Lagu Ayam Den Lapeh Garapan Orkes Gumarang.

Marzam, D., \& Mansyur, H. (2018). Tourist Art Packaging Randai Performance in Seribu Rumah Gadang Area Jorong Lubuk Jaya Nagari Koto Baru, Solok Selatan Regency, West Sumatra. INA-Rxiv. October, 22.

Moleong, L. J. (2002). Metode penelitian kualitatif. Bandung: Rosda Karya.

Wuri, J. M., Wimbrayardi, W., \& Marzam, M. (2015). Upaya Pelestarian Musik Talempong Pacik di Kecamatan Koto XI Tarusan Kabupaten Pesisir Selatan. Jurnal Sendratasik, 4(1), 77-88. 